\title{
Survei Larva Nyamuk Aedes Vektor Demam Berdarah Dengue di Kelurahan Kuranji Kecamatan Kuranji Kotamadya Padang Provinsi Sumatera Barat
}

\author{
Muhammad Arifudin ${ }^{1}$, Adrial $^{2}$, Selfi Renita Rusjdi ${ }^{3}$
}

\begin{abstract}
Abstrak
Demam berdarah dengue merupakan salah satu masalah kesehatan masyarakat yang masih ditemukan di Indonesia. Penyakit ini disebabkan oleh virus Dengue yang ditularkan melalui gigitan nyamuk Aedes. Kelurahan Kuranji merupakan kelurahan dengan kasus demam berdarah dengue terbanyak di Kota Padang. Tujuan penelitian ini adalah menentukan density figure (kepadatan) larva nyamuk Aedes di Kelurahan Kuranji Padang. Penelitian dilaksanakan di Kelurahan Kuranji pada bulan April 2014. Desain penelitian adalah survei deskriptif dengan jumlah sampel 50 buah rumah yang diambil dengan cara multistage sampling. Hasil penelitian menunjukkan bahwa aedes aegypti ditemukan lebih banyak dibandingkan aedes albopictus, yaitu 97,74\%. house index yaitu 52,50\%, container index yaitu $34,72 \%$, breteau index yaitu $66,50 \%$ dan density figure yaitu 7 . Hasil penelitian ini menunjukkan bahwa aedes aegypti lebih banyak ditemukan di dalam rumah dan aedes albopictus hanya ditemukan di luar rumah. Bak mandi dari semen merupakan kontainer yang paling banyak ditemukan larva Aedes dibandingkan jenis kontainer lain.
\end{abstract}

Kata kunci: dengue, aedes, density figure

\begin{abstract}
Dengue haemorraghic fever is one of important public health problem in Indonesia. This disease is caused by the dengue virus which is transmitted by Aedes bytes. Kuranji is the most prevalent dengue haemorraghic fever in Padang. The objective of this study was to determine density figure in Kuranji district. This research had been held in Kuranji district in April 2014. The design was descriptive survey research method. The number of sampel was 50 that was taken by multi stage sampling method. The result showed that aedes aegypti found more than aedes albopictus, about $97.74 \%$. house index 52.50\%, container index $34.72 \%$, breteau index $66.50 \%$ and density figure 7 . The research showed that Aedes aegypti is mostly found at house and aedes albopictus only found outdoor. The bath tank which are made from cement is the most comfortable breeding place for Aedes Aegypti rather than other containers.
\end{abstract}

Keywords: dengue, aedes, density figure

Affiliasi penulis: 1. Pendidikan Dokter FK UNAND (Fakultas Kedokteran Universitas Andalas Padang), 2. Bagian Parasitologi FK UNAND, 3. Bagian Parasitologi FK UNAND.

Korespondensi: Muhammad Arifudin, Email:areifhz@gmail.com, Telp: 085669090559

\section{PENDAHULUAN}

Aedes adalah nyamuk yang menularkan virus dengue ke manusia melalui gigitannya. Aedes aegypti merupakan vektor epidemik yang paling utama, namun spesies Aedes (Ae.) yang lain seperti $A e$. albopictus, Ae. polynesiensis dan Ae. niveus dianggap sebagai vektor sekunder karena spesies ini memiliki daerah distribusi geografis yang khas dan terbatas. merupakan Nyamuk-nyamuk tersebut merupakan host yang baik untuk virus dengue, tetapi kurang efisien sebagai vektor epidemi dibandingkan Ae. aegypti. ${ }^{1}$ Aedes aegypti tersebar luas di wilayah tropis dan subtropis Asia Tenggara, seperti di Indonesia. Aedes albopictus merupakan salah satu spesies Aedes yang tersebar kearah Kepulauan Afrika Timur, Filipina dan beberapa kawasan Asia. Di wilayah tropis Asia, penting untuk membedakan vektor di perkotaan dan 
pedesaan. Di perkotaan, Ae. aegypti biasanya ditemukan dan hampir selalu menggigit didalam rumah, sementara itu $A e$. albopictus sering ditemukan di kebun dan pepohonan dengan aktivitas menggigit lebih sering diluar rumah. Di daerah pedesaan $A e$. albopictus biasanya lebih sering ditemukan daripada Ae. aegypti. ${ }^{2}$

Manusia lebih sering terpapar oleh gigitan $A e$. aegypti dibandingkan spesies Aedes lainnya. Terutama dalam aktivitas menggigit nyamuk didalam dan diluar rumah, ketertarikan terhadap darah manusia, kesanggupan mengisap darah beberapa kali dan kesanggupan bertahan terhadap kering dan temperatur rendah dalam stadium telur menjadikannya sebagai vektor utama Demam Berdarah Dengue. ${ }^{2}$ Demam Berdarah Dengue (DBD) disebabkan oleh virus dengue, yang termasuk dalam genus Flavivirus, keluarga Flaviviridae. Flavivirus merupakan virus dengan diameter $30 \mathrm{~nm}$, terdiri dari asam ribonukleat rantai tunggal dengan berat molekul $4 \times 10^{6}$. Terdapat 4 serotipe virus yaitu DEN-1, DEN-2, DEN-3 dan DEN4 yang semuanya dapat menyebabkan DBD. Keempat serotip ini ditemukan di Indonesia dengan DEN-3

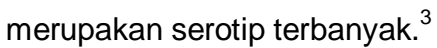

Data menunjukkan Asia menempati urutan pertama dalam jumlah penderita DBD setiap tahunnya. World Health Organization (WHO) mencatat negara Indonesia sebagai negara dengan kasus DBD tertinggi di Asia Tenggara terhitung sejak tahun 1968 hingga 2009. ${ }^{4}$ Berdasarkan data dari Kemenkes RI, DBD merupakan penyakit terbesar kedua yang dirawat inap di rumah sakit di Indonesia pada tahun 2010. Kasus DBD di Indonesia tahun 2011 berjumlah 65.432 kasus dengan kematian 595 orang dan Case Fatality Rate (CFR) 0,91\%. Provinsi urutan pertama dalam jumlah penderita DBD yaitu Jawa Barat dengan 13.836 kasus dan CFR 0,41\%. Sementara itu Sumatera Barat menempati urutan kesembilan dengan 2.202 jumlah kasus dan CFR 0,64\%. ${ }^{1}$ Kasus DBD tahun 2011 di Provinsi Sumatera Barat banyak ditemukan di Kota Padang dibandingkan kabupaten/kota lainnya, dengan jumlah 755 kasus. $^{5}$ Tahun 2013, kasus DBD di Kota Padang yaitu 998 kasus, mengalami peningkatan dibandingkan dua tahun sebelumnya. Kejadian DBD terbanyak yaitu di Kecamatan Kuranji dengan 127 kasus, dimana
Kelurahan Kuranji sebagai kasus DBD terbanyak yaitu 71 kasus. Di kelurahan tersebut, kasus tertinggi ditemukan di RW 17 yaitu 10 kasus. $^{6}$

Pengobatan DBD pada dasarnya lebih bersifat suportif, yaitu mengatasi kehilangan atau perpindahan cairan plasma sebagai akibat peningkatan permeabilitas kapiler dan sebagai akibat perdarahan. ${ }^{7}$ Saat ini vaksin dan obat DBD masih dalam proses penelitian, oleh karena itu pengendalian DBD yang tepat adalah dengan pemutusan rantai penularan melalui pengendalian vektornya. ${ }^{1}$

Pengendalian vektor ini dilakukan dengan berbagai cara, yaitu perlindungan perorangan, mencegah nyamuk meletakkan telurnya di tempat perindukan, mencegah pertumbuhan larva, pemberian larvisida, melakukan fogging dengan malathion didaerah wabah atau endemik, dan pendidikan kesehatan masyarakat agar memelihara lingkungan. ${ }^{8}$ Kegiatan yang berfokus untuk menurunkan populasi larva dengan kerjasama antar sektor dan masyarakat dianggap penting dalam usaha pengendalian vektor DBD agar membawa hasil yang maksimal. ${ }^{9}$

\section{METODE}

Jenis penelitian yang dilakukan adalah survei deskriptif. Penelitian dilakukan di Kelurahan Kuranji Kecamatan Kuranji Kota Padang dan identifikasi larva dilaksanakan di laboratorium parasitologi Fakultas Kedokteran Universitas Andalas. Penelitian dilaksanakan pada bulan April 2014. Populasi pada penelitian ini adalah seluruh larva nyamuk yang ditemukan dirumah yang ada di kelurahan Kuranji. Sampel pada penelitian ini diambil secara multistage sampling, dengan jumlah sampel 50 rumah yang dibagi secara proposional di RW dan RT terpilih. Prosedur pengambilan data yaitu :

\section{a. Pengambilan larva di lapangan}

Survei larva dilakukan dengan cara mengambil larva yang ditemukan di kontainer di dalam dan di luar rumah. Untuk memeriksa TPA yang berukuran besar seperti bak mandi, ban bekas, dan bak penampungan air lainnya, jika pada pandangan pertama tidak ditemukan larva, tunggu kira-kira satu menit untuk memastikan bahwa larva benar-benar tidak ada. Untuk memeriksa tempat berkembang biak yang kecil seperti 
penampung air dispenser, pot bunga dan botol, maka air didalamnya perlu dipindahkan ke tempat lain. Pemeriksaan larva ditempat yang agak gelap atau airnya keruh digunakan lampu senter.

Survei larva dapat dilakukan dengan single larva method yaitu dengan mengambil satu larva di setiap TPA lalu diidentifikasi. Larva yang diambil dimasukkan ke dalam tabung penyimpanan yang berisi air atau alkohol 70\%, kemudian diberi keterangan berupa tempat pengambilan dan tanggal pengambilan larva. Setelah itu larva diidentifikasi di laboratorium. Larva diambil setiap 5-7 hari selama empat kali pengambilan. Pengambilan larva akan dibantu oleh beberapa kader dan relawan.

b. Identifikasi larva di laboratorium

Identifikasi larva dilakukan dengan cara melihat morfologi larva dibawah mikroskop dengan perbesaran 10 kali. Bila hasil identifikasi menunjukkan Ae. aegypti maka seluruh larva dari tempat cidukan sampel tersebut dinyatakan sebagai larva Ae. aegypti. Identifikasi larva bertujuan untuk menentukan jenis larva nyamuk yang diteliti. Pada penelitian ini, hanya larva Aedes yang dicatat dan disajikan dalam tabel. Pengolahan data dilakukan secara manual dan kemudian disajikan dalam bentuk tabel distribusi frekuensi.

\section{HASIL}

Kelurahan Kuranji terletak di Kecamatan Kuranji, Kota Padang. Kelurahan ini terdiri dari 18 RW dan 88 RT dengan jumlah kepala keluarga sekitar 8311 orang. Kelurahan ini merupakan wilayah dengan kasus DBD tertinggi di Kota Padang tahun 2013. Dari penelitian yang telah dilakukan di Kelurahan Kuranji, Kecamatan Kuranji, Kota Padang pada bulan April
2014, didapatkan hasil penelitian yang dapat dilihat pada tabel-tabel berikut.

Berdasarkan Tabel 1 terlihat bahwa spesies larva yang ditemukan selama penelitian ternyata didominasi oleh $A e$. aegypti, baik didalam maupun diluar rumah. Larva Ae. aegypti ditemukan sekitar $83,20 \%$ didalam rumah dan $14,50 \%$ diluar rumah. Sementara itu, Ae. albopictus ditemukan hanya diluar rumah yaitu sekitar $2,26 \%$.

Tabel 1. Distribusi spesies larva nyamuk Aedes di Kelurahan Kuranji Padang

\begin{tabular}{|c|c|c|c|c|c|c|c|c|c|}
\hline \multirow{2}{*}{\multicolumn{2}{|c|}{ Lokasi }} & \multicolumn{8}{|c|}{ Spesies larva } \\
\hline & & \multicolumn{4}{|c|}{ Dalam rumah } & \multicolumn{4}{|c|}{ Luar rumah } \\
\hline $\mathrm{RW}$ & RT & $A e$. & $(\%)$ & Al. & $(\%)$ & Ae. & $(\%)$ & Al. & $(\%)$ \\
\hline 8 & 5 & 21 & 16,03 & 0 & 0,00 & 7 & 5,34 & 0 & 0,00 \\
\hline 8 & 8 & 2 & 1,52 & 0 & 0,00 & 1 & 0,07 & 0 & 0,00 \\
\hline 11 & 2 & 9 & 6,87 & 0 & 0,00 & 3 & 2,29 & 3 & 2,29 \\
\hline 11 & 7 & 11 & 8,39 & 0 & 0,00 & 3 & 2,29 & 0 & 0,00 \\
\hline 12 & 3 & 12 & 9,16 & 0 & 0,00 & 3 & 2,29 & 0 & 0,00 \\
\hline 12 & 4 & 29 & 22,13 & 0 & 0,00 & 0 & 0,00 & 0 & 0,00 \\
\hline 17 & 3 & 2 & 1,52 & 0 & 0,00 & 2 & 1,52 & 0 & 0,00 \\
\hline \multirow[t]{2}{*}{17} & 5 & 23 & 17,55 & 0 & 0,00 & 0 & 0,00 & 0 & 0,00 \\
\hline & & 109 & 83,20 & 0 & 0,00 & 19 & 14,50 & 3 & 2,29 \\
\hline \multicolumn{2}{|c|}{ Total } & \multicolumn{8}{|c|}{131} \\
\hline
\end{tabular}

Berdasarkan lokasi penelitian didalam rumah, terlihat larva Ae. aegypti banyak ditemukan di RW 12, RT 4 yaitu 22,13\% dan paling sedikit ditemukan di RW 8, RT 8 dan RW 17, RT 3 yaitu sama-sama 1,52\%. Sementara itu Ae. albopictus tidak ditemukan di dalam rumah. Pada lokasi di luar rumah, larva Ae. aegypti ditemukan terbanyak di RW 8, RT 5 yaitu sekitar 5,34\%, dan tidak ditemukan di RW 12, RT 4 dan RW 17, RT 5 yaitu sama-sama 0,00\%. Sedangkan larva Ae. albopictus hanya ditemuan di RW 11, RT 2 yaitu sekitar 2,29\%.

Tabel 2. Kepadatan larva nyamuk Aedes di Kelurahan Kuranji Padang

\begin{tabular}{|c|c|c|c|c|c|c|c|c|}
\hline \multicolumn{2}{|c|}{ Lokasi } & \multicolumn{2}{|c|}{ House Index } & \multicolumn{2}{|c|}{ Container Index } & \multicolumn{2}{|c|}{ Breteau Index } & \multirow[t]{2}{*}{ Rerata DF } \\
\hline RW & RT & (\%) & NDF & (\%) & NDF & $(\%)$ & NDF & \\
\hline 8 & 5 & 55,55 & 7 & 29,78 & 7 & 77,77 & 7 & 7 \\
\hline 8 & 8 & 18,75 & 4 & 10,00 & 4 & 18,75 & 3 & 4 \\
\hline 11 & 2 & 68,75 & 8 & 34,09 & 8 & 93,75 & 7 & 8 \\
\hline 11 & 7 & 56,25 & 7 & 35,00 & 8 & 87,50 & 7 & 7 \\
\hline 12 & 3 & 37,50 & 5 & 34,09 & 8 & 46,87 & 5 & 6 \\
\hline 12 & 4 & 69,44 & 8 & 55,76 & 9 & 80,55 & 7 & 8 \\
\hline 17 & 3 & 25,00 & 4 & 16,66 & 5 & 25,00 & 4 & 4 \\
\hline 17 & 5 & 68,75 & 8 & 46,00 & 9 & 71,87 & 6 & 8 \\
\hline & & 53,00 & 7 & 34,38 & 8 & 65,50 & 6 & 7 \\
\hline
\end{tabular}


Berdasarkan Tabel 2 terlihat bahwa kepadatan vektor DBD di Kelurahan Kuranji pada bulan April 2014 berdasarkan House Index yaitu 53,00\%, dengan angka tertinggi di RW 12, RT 4 yaitu sekitar $69,44 \%$ dan angka terendah di RW8, RT 8 yaitu sekitar $18,75 \%$. Container Index yaitu 34,38\%, tertinggi di RW 12, RT 4 yaitu 55,76\% dan angka terendah di RW 8, RT 8 yaitu 10,00\%. Breteau Index yang didapatkan yaitu $65,50 \%$, angka tertinggi yaitu $93,75 \%$ di temukan di RW 11, RT 2 dan angka terendah yaitu 18,75\% ditemukan di RW 8, RT 8. Density Figure yang didapatkan di Kelurahan Kuranji yaitu 7, dimana angka tertinggi ditemukan di RW 11, RT 2; RW 12, RT 4; dan RW 17, RT 5 yaitu sama-sama 8, sedangkan angka terendah ditemukan di RW 8, RT 8 dan RW 17, RT 3 yaitu sama-sama 4

Tabel 3. Distribusi larva nyamuk Aedes berdasarkan letak kontainer didalam/diluar rumah di Kelurahan Kuranji Padang

\begin{tabular}{|c|c|c|c|c|c|c|c|}
\hline \multicolumn{2}{|c|}{ Lokasi } & \multicolumn{3}{|c|}{ Dalam rumah } & \multicolumn{3}{|c|}{ Luar rumah } \\
\hline RW & RT & $\begin{array}{l}\text { Perik } \\
\text { sa }\end{array}$ & $(+)$ & (\%) & $\begin{array}{l}\text { Perik } \\
\text { sa }\end{array}$ & $(+)$ & (\%) \\
\hline 8 & 5 & 69 & 21 & 5,51 & 27 & 7 & 1,83 \\
\hline 8 & 8 & 28 & 2 & 0,52 & 2 & 1 & 0,26 \\
\hline 11 & 2 & 28 & 9 & 2,36 & 16 & 6 & 1,57 \\
\hline 11 & 7 & 28 & 11 & 2,88 & 12 & 3 & 0,78 \\
\hline 12 & 3 & 40 & 12 & 3,14 & 4 & 3 & 0,78 \\
\hline 12 & 4 & 52 & 29 & 7,61 & 0 & 0 & 0,00 \\
\hline 17 & 3 & 22 & 2 & 0,52 & 2 & 2 & 0,52 \\
\hline 17 & 5 & 51 & 23 & 6,03 & 0 & 0 & 0,00 \\
\hline \multirow{2}{*}{\multicolumn{2}{|c|}{ Total }} & 318 & 109 & 28,8 & 63 & 22 & 5,77 \\
\hline & & \multicolumn{6}{|c|}{381} \\
\hline
\end{tabular}

Tabel 3 terlihat bahwa kepadatan vektor DBD berdasarkan letak kontainer, kepadatan larva Aedes lebih tinggi ditemukan didalam rumah dibandingkan di luar rumah. Hal ini terlihat dari kontainer di dalam rumah yang positif dengan larva Aedes yaitu 109 kontainer dari 381 kontainer yang diperiksa. Kontainer di luar rumah yang positif dengan larva Aedes yaitu 22 kontainer dari 381 kontainer yang diperiksa. Angka kepadatan vektor tertinggi untuk pemeriksaan didalam rumah ditemukan di RW 12, RT 4 yaitu 7,61\% dan angka tertinggi di luar rumah ditemukan di RW 11, RT 2 yaitu $1,57 \%$.
Tabel 4. Distribusi larva nyamuk Aedes berdasarkan jenis kontainer di Kelurahan Kuranji, Padang, pada survei bulan April 2014.

\begin{tabular}{|c|c|c|c|c|c|c|}
\hline \multirow[t]{3}{*}{ No } & \multirow[t]{3}{*}{$\begin{array}{c}\text { Jenis } \\
\text { kontainer }\end{array}$} & \multicolumn{4}{|c|}{$\begin{array}{c}\text { Jumlah kontainer yang } \\
\text { diperiksa }\end{array}$} & \multirow[t]{3}{*}{ (\%) } \\
\hline & & \multicolumn{2}{|c|}{ Dalam rumah } & \multicolumn{2}{|c|}{ Luar rumah } & \\
\hline & & Jmh & $(+)$ & Jmh & $(+)$ & \\
\hline 1 & $\begin{array}{l}\text { Bak mandi } \\
\text { dari semen }\end{array}$ & 100 & 44 & & & 11,54 \\
\hline 2 & $\begin{array}{l}\text { Bak mandi } \\
\text { dari keramik }\end{array}$ & 64 & 15 & & & 3,93 \\
\hline 3 & $\begin{array}{l}\text { Bak mandi } \\
\text { dari plastik }\end{array}$ & 36 & 6 & & & 1,57 \\
\hline 4 & Dispenser & 71 & 29 & & & 7,61 \\
\hline 5 & Kulkas & 32 & 5 & & & 1,31 \\
\hline 6 & Ember & 15 & 10 & & & 2,62 \\
\hline & plastik & & & 23 & 14 & 3,67 \\
\hline 7 & $\begin{array}{l}\text { Tempat } \\
\text { minum } \\
\text { burung }\end{array}$ & & & 24 & 0 & $0,00 \%$ \\
\hline 8 & Ban bekas & & & 10 & 6 & $1,57 \%$ \\
\hline 9 & Kaleng & & & 6 & 2 & $0,52 \%$ \\
\hline 10 & Pot bunga & & & 0 & 0 & $0,00 \%$ \\
\hline & $\begin{array}{l}\text { Total } \\
\text { kontainer }\end{array}$ & 318 & 109 & 63 & 22 & 381 \\
\hline
\end{tabular}

Pada Tabel 4 terlihat bahwa berdasarkan tempat perindukan, larva Aedes paling banyak ditemukan di bak mandi semen di dalam rumah $(11,54 \%)$ diikuti dispenser $(7,61 \%)$, dan di luar rumah banyak ditemukan di ember plastik (3,67\%). Pada tempat minum burung tidak ditemukan larva $(0,00 \%)$, dan tidak dilakukan pemeriksaan larva di pot bunga, karena tidak memiliki genangan air.

\section{PEMBAHASAN}

Survei larva yang dilakukan di Kelurahan Kuranji pada bulan April 2014 telah memberikan hasil gambaran tentang distribusi spesies larva, kepadatan larva berdasarkan indikator pengamatan, kepadatan berdasarkan letak kontainer dan kepadatan berdasarkan jenis kontainer. Kepadatan larva berdasarkan indikator pengamatan didapatkan hasil berupa house index yaitu 53,00\%, container index yaitu $34,38 \%$, breteau index yaitu $65,50 \%$ dan density figure yaitu 7 .

Berdasarkan spesies larva selama penelitian, Aedes aegypti lebih banyak ditemukan daripada $A e$. albopictus. Aedes aegypti ditemukan sekitar 83,20\% 
didalam rumah dan $14,50 \%$ diluar rumah, sedangkan Ae. albopictus hanya ditemukan diluar rumah, yaitu sekitar 2,29\%. Hal ini menunjukkan bahwa Ae. aegypti lebih menyukai tempat perindukan di dalam rumah dibandingkan di luar rumah. Sementara itu, Ae. albopictus yang tidak ditemukan di dalam rumah, dan hanya ditemukan diluar rumah menunjukkan bahwa Ae. albopictus lebih menyukai tempat perindukan diluar rumah. WHO menyatakan Ae. aegypti biasanya beraktifitas dan istirahat didalam rumah. ${ }^{9}$ Soedarmo menyatakan Ae. albopictus biasanya beraktifitas dan istirahat di luar rumah. ${ }^{2}$ Banyaknya ditemukan $A e$. aegypti dibandingkan Ae. albopictus ini sesuai dengan penelitian Taufan pada tahun 2004 di Bandar Purus dimana ditemukan Ae. aegypti $94,87 \%$ dan $A e$. albopictus hanya $5,12 \%{ }^{10}$

Berdasarkan lokasi penelitian didalam rumah, terlihat larva Ae. aegypti banyak ditemukan di RW 12, RT 4 yaitu 22,13\% dan paling sedikit ditemukan di RW 8, RT 8 dan RW 17, RT 3 yaitu sama-sama 1,52\%. Sementara itu Ae. albopictus tidak ditemukan di dalam rumah. Berdasarkan lokasi di luar rumah, larva $A e$. aegypti ditemukan terbanyak di RW 8, RT 5 yaitu sekitar 5,34\%, dan paling sedikit ditemukan di RW 12 , RT 4 dan RW 17, RT 5 yaitu sama-sama 0,00\%. Sedangkan larva Ae. albopictus hanya ditemuan di RW 11, RT 2 yaitu sekitar 2,29\%. Larva Ae. aegypti di dalam rumah banyak ditemukan di RW 12, RT 4, hal ini berhubungan dengan banyaknya kontainer yang ditemukan di dalam rumah penduduk yang kurang diperhatikan sehingga potensial sebagai tempat perindukan nyamuk Ae. aegypti. Banyaknya larva Ae. aegypti di luar rumah yang ditemukan di RW 8, RT 5, juga disebabkan oleh banyaknya kontainer yang ditemukan di luar rumah penduduk yang kurang diperhatikan sehingga pada saat setelah hujan akan menjadi kontainer yang potensial sebagai tempat perindukan nyamuk Ae. aegypti. Larva Ae. albopictus yang hanya ditemukan di RW 11, RT 2 mungkin disebabkan lokasi pemukiman ini yang berbatasan dengan perkebunan.

Berdasarkan indikator kepadatan larva, didapatkan house index yaitu 53,00\% merupakan angka yang cukup tinggi, dikarenakan pemukiman penduduk di Kelurahan Kuranji yang padat di kawasan perumahan sehingga memudahkan nyamuk untuk berpindah dari satu rumah ke rumah lainnya. House index mencapai angka tertinggi di RW 12, RT 4 yaitu sekitar 69,44\% dan terendah di RW 8, RT 8 yaitu $18,75 \%$. Hal ini dipengaruhi sikap dan perilaku penduduk dalam pengelolaan tempat penampungan air. Faktor jenis tempat penyimpanan air oleh masyarakat juga berpengaruh, dimana di RW 12, RT 4 banyak rumah penduduk yang memakai bak mandi dari semen dibandingkan di RW 8, RT 8. Bak mandi dari semen merupakan tempat perindukan yang paling disukai nyamuk Aedes, sebagaimana hasil penelitian ini. Angka house index ini tidak jauh berbeda dengan penelitian yang dilakukan Adrial pada tahun 2006 di Bandar Purus, Kota Padang, yaitu berkisar 55,50\%. ${ }^{11}$

Container index dengan rata-rata $34,38 \%$ tergolong tinggi. Angka tertinggi di RW 12, RT 4 yaitu $55,76 \%$ dan angka terendah di RW 8, RT 8 yaitu $10,00 \%$. Tingginya container index ini dikarenakan kondisi pemukiman yang kurang bersih, banyaknya tempat perindukan nyamuk yang potensial seperti bak mandi semen, dispenser, ember plastik yang menampung air hujan, ban bekas dan tempat penampungan air lainnya yang kurang dikelola dengan baik sehingga vektor mudah berkembangbiak. Tingginya angka container index ini juga dikarenakan perilaku sebagian masyarakat yang kurang peduli dengan lingkungan, seperti jarang membersihkan bak mandi dan dispenser, meletakkan ember atau ban bekas di luar rumah. Sementara itu, angka Container Index yang rendah di RW 8, RT 8 disebabkan kontainer yang ditemukan terlihat dikelola dengan baik, sehingga tidak efektif sebagai tempat perindukan nyamuk. Container Index di Kelurahan Kuranji ini lebih rendah dibandingkan penelitian Adrial pada tahun 2006 di Bandar Purus, Kelurahan Padang Pasir, Kecamatan Padang Barat yaitu 43,00\%. ${ }^{11}$

Breteau Index sekitar 65,50\% menunjukkan kepadatan dan penyebaran vektor di kelurahan Kuranji cukup tinggi. Angka ini berhubungan dengan banyaknya ditemukan kontainer yang positif larva Aedes di setiap rumah. Angka ini lebih tinggi dibandingkan peneltian Muhammad pada tahun 2002 di Kelurahan Jati yaitu 23,12\%. ${ }^{12} \mathrm{Hal}$ ini dipengaruhi oleh perilaku masyarakat dalam mengelola tempat penampungan air. Selain itu, kondisi rumah yang padat juga mempengaruhi mudahnya penyebaran 
nyamuk aedes untuk berkembang biak dari satu rumah ke rumah lainnya. Density figure di Kelurahan Kuranji yaitu 7, artinya daerah Kuranji beresiko tinggi dalam penularan DBD. Angka tertinggi ditemukan di RW 11, RT 2; RW 12, RT 4; dan RW 17, RT 5 yaitu 8. Angka terendah ditemukan di RW 8, RT 8 dan RW 17, RT 3 yaitu 4. Tingginya angka density figure ini berkaitan dengan tingginya nilai indikator kepadatan larva aedes, yaitu $\mathrm{HI}, \mathrm{Cl}$ dan $\mathrm{BI}$. Jika terjadi kasus DBD, maka penyebarannya lebih mudah karena banyaknya ditemukan vektor dikawasan tersebut. Perilaku masyarakat untuk menampung air, tidak menguras bak mandi secara teratur, membuang barang bekas berupa botol plastik/kaca yang dapat menampung air hujan dan adanya tanaman hias yang rimbun juga mempengaruhi keberadaan nyamuk aedes. $^{10}$

Distribusi larva nyamuk aedes berdasarkan letak kontainer di dalam/luar rumah menunjukkan bahwa kepadatan larva lebih tinggi di dalam rumah $(28,83 \%)$ di bandingkan di luar rumah (5,77\%). Hal ini memperlihatkan bahwa vektor DBD di kelurahan Kuranji lebih menyukai tempat perindukan di dalam rumah di bandingkan di luar rumah. Ini dikarenakan banyaknya tempat perindukan yang disukai nyamuk, seperti kondisi air yang jernih, suasana rumah sedikit gelap, dan tempat perindukan yang jarang diperiksa dan dibersihkan. Kontainer yang di luar rumah juga cukup disenangi, hal ini karena tempat perindukan $\mathrm{d}$ luar rumah yang dibiarkan saja sehingga menjadi tempat perindukan nyamuk. Bila dibandingkan dengan penelitian Taufan pada tahun 2004 di Bandar Purus, kepadatan larva didalam rumah yaitu $17,06 \%$, lebih tinggi dibandingkan diluar rumah yaitu 12,07\%. Meskipun sama-sama ditemukan kepadatan didalam rumah lebih tinggi dibandingkan di luar rumah, namun kepadatan larva didalam rumah di Kelurahan Kuranji lebih tinggi dibandingkan dengan penelitian Taufan dan sebaliknya kepadatan larva diluar rumah di Kelurahan Kuranji lebih rendah dibandingkan dengan penelitian Taufan pada tahun 2004. Hal ini dikarenakan perbedaan jumlah dan rasio kontainer yang ditemukan antara didalam rumah dan diluar rumah pada penelitian di Kelurahan Kuranji dan penelitian Taufan yang berpengaruh terhadap hasil penelitian. Rasio jumlah kontainer didalam rumah dan diluar rumah antara penelitian di Kelurahan Kuranji dan penelitian Taufan yaitu $5: 1$ dan $1,1: 1^{10}$

Berdasarkan tempat perindukannya, larva aedes paling banyak ditemukan di bak mandi semen di dalam rumah (11,54\%). Hal ini disebabkan dinding bak mandi dari semen bersifat kasar, mudah menyerap air dan gelap sangat disukai Ae. aegypti untuk meletakkan telurnya. ${ }^{13}$ Irawati dalam penelitiannya tahun 1999 juga menemukan banyak larva di bak mandi dari semen, di perumahan Siteba, Padang. ${ }^{14} \mathrm{Hal}$ ini menunjukkan bahwa bak mandi dari semen masih disukai Aedes sebagai tempat perindukan. Urutan kedua yaitu dispenser (7,61\%), dikarenakan jarang dibersihkan sehingga air yang tergenang di dispenser memungkinkan nyamuk meletakkan telurnya. Kontainer di luar rumah banyak ditemukan di ember plastik (3,67\%), karena ember ini digunakan untuk menampung air hujan dan tidak dibersihkan oleh masyarakat sekitar. Satu satunya tempat perindukan yang tidak ditemukan larva yaitu di tempat minum burung, hal ini dikarenakan para pemelihara burung yang cukup rajin mengganti airnya, biasanya sekali dalam satu hingga tiga hari.

\section{KESIMPULAN}

Density Figure yaitu 7, artinya Kelurahan Kuranji beresiko tinggi dalam penularan DBD. Larva Aedes lebih banyak ditemukan di dalam rumah $(28,83 \%)$ di bandingkan di luar rumah $(5,77 \%)$. Larva Aedes paling banyak ditemukan di bak mandi semen di dalam rumah $(11,54 \%)$

\section{DAFTAR PUSTAKA}

1. Kementerian Kesehatan Republik Indonesia. Modul pengendalian demam berdarah dengue. Jakarta: Kemenkes RI; 2011.

2. Soedarmo, Poorwo SS. Demam berdarah (dengue) pada anak. Jakarta: Penerbit UI; 2005.

3. Suhendro, Leonardo N, Khie C, Herdiman TP. Demam berdarah dengue. Dalam: Buku Ajar IImu Penyakit Dalam. Edisi Ke-5. Jakarta: Pusat Penerbitan Departemen IImu Penyakit Dalam FKUI; 2006. hlm.1709.

4. Pusat Data dan Surveilans Epidemiologi Kemenkes. Demam berdarah dengue di Indonesia 
Tahun 1968 - 2009. Buletin Jendela Epidemiologi, 2010.

5. Dinas Kesehatan Sumatera Barat. Data kasus DBD 2011. Padang; 2011.

6. Dinas Kesehatan Kota Padang. Data kasus DBD 2013. Padang; 2013.

7. Nasronudin. Penyakit infeksi di Indonesia \& solusi kini dan mendatang. Surabaya: Airlangga University Press; 2007.

8. Natadisastra. Parasitologi kedokteran ditinjau dari organ tubuh yang diserang. Jakarta: Penerbit Buku EGC; 2009.

9. World Health Organization. Panduan lengkap pencegahan \& pengendalian dengue \& demam berdarah dengue. Jakarta: EGC; 2005.

10. Taufan F. Gambaran kepadatan vektor demam berdarah dengue di Bandar Purus Kodya Padang. (skripsi). Padang: Universitas Andalas; 2004.

11. Adrial. Beberapa aspek indikator entomologi nyamuk aedes spp. dalam rangka perencanaan pengendalian vektor penyakit demam berdarah dengue (DBD) di Kecamatan Padang Barat, Kodya Padang. MKA. 2006;3(2): 67.

12. Muhammad A. Gambaran kepadatan vektor demam berdarah dengue di Kelurahan Jati Kecamatan Padang Timur Kota Padang (skripsi). Padang:Universitas Andalas; 2002.

13. Sungkar. Pemberantasan demam berdarah dengue sebuah tantangan yang harus dijawab. MKI. 2007; 57(6):168.

14. Irawati. Kepadatan vektor demam berdarah dengue di perumnas Siteba Padang tahun 19992000. Jurnal Matematika \& Pengetahuan Alam. 1999; 9: 24. 